\title{
The Significance of Alexander's Three Hundred Suits of Armor
}

\author{
Changchang Fan*
}

Nanjing Foreign Language School, Nanjing, Jiangsu 210008, China
Myra2026@hotmail.com

\begin{abstract}
This paper analyzes the significance of the three hundred suits of armor that Alexander the Great inscribed after the Battle of Granicus. Starting from the introduction of the early days in Alexander's reign, this paper goes through introducing the reluctance of Alexander as king from the Greeks to analyzing the inscription on the 300 pieces of armor and winning the hearts of his men. The armor, indeed, did play a significant part in uniting Alexander's army and ascending his leadership. Although Alexander has been exposed to the outside world as a powerful leader, this paper elaborates more on how Alexander gained trust and reverence among his men and what the specific inscriptions contributed to Alexander's success in his entire lifetime and what it reveals about Alexander himself, especially his unique vision.
\end{abstract}

Keywords: Battle of Granicus, Alexander the Great, 300 suits of armor, Greek, Persia

\section{INTRODUCTION}

Alexander the Great. The name of the incredible leader who conquered the most land gradually becomes this tangible historical figure through the narratives of ancient historians combined. Though many stories of this great king remain fragmentary, the anecdote of Alexander inscribing a message on the 300 Persian Armor after the Battle of Granicus appears to be one of the few bestdocumented stories among ancient sources.

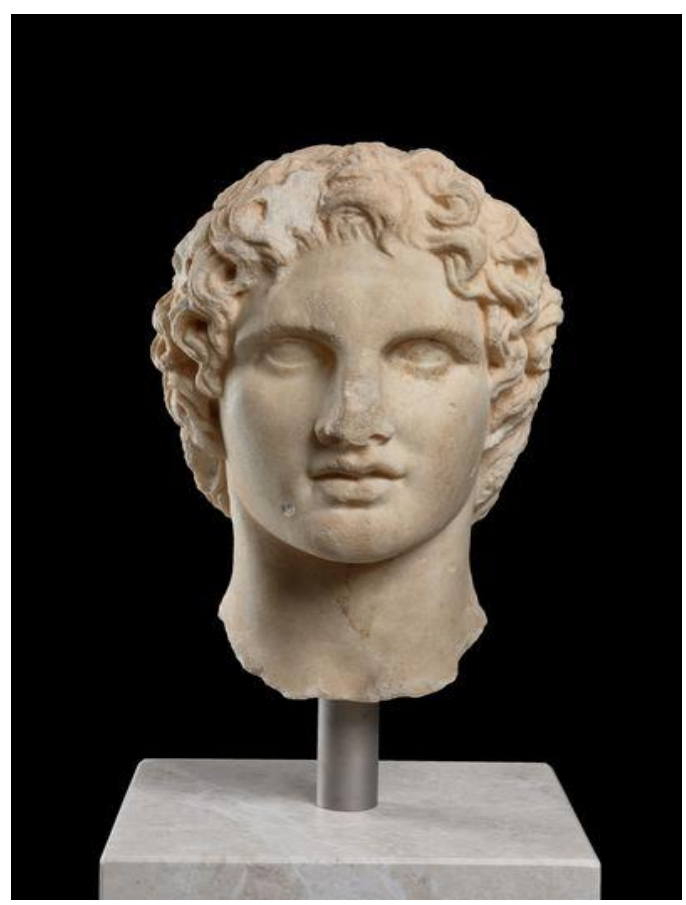

Figure 1 Head of a statue of Alexander the Great

The Battle of Granicus was the first impactful defeat that Alexander offered the Persians. He remained respectful and treated the dead from both parties with great military honors after the battle. He also dedicated the 300 suits of Persian armor, according to Arrian, to 
Athena to be hung on Acropolis with the greek inscription: "Alexander, son of Philip, and all the Greeks except the Lacedaemonians, present this offering from the spoils taken from the foreigners inhabiting Asia[1]." It was the spring of 334 B.C.E., and this noteworthy victory that led Alexander into Asia Minor to fulfill further conquests.

\section{EARLY DAYS IN ALEXANDER'S REIGN}

Nothing could be better at signifying success than pieces of armor, needless to say, 300 Armor. These suits of Persian armor were an indication of Alexander's success at the Battle of Granicus and were proof of Alexander's military competency. They were indeed to remind Greeks of the history of the Greco-Persian war and to stimulate their enthusiasm towards revenge. When Alexander's father Philip II of Macedon was powerful enough to dominate Greece, he organized the Corinth League in 359 B.C.E. to seek revenge on the Persians and expand his territory. Only the city-state Sparta remained out of the league as they saw themselves higher above other people and refused to enter[2]. When Philip was assassinated in 356 B.C.E., Alexander had no choice but to take on the Corinth League as a 21-year-old young boy. The greeks, at that point, were not very supportive of Alexander. According to Plutarch, Athens, a major Greek city-state held a thanksgiving celebration for the death of Philip to Zeus and Athena along with an anti-Alexander call. Another major state Thebes voted to expel the Macedonian garrison and the Eleians seek to regain independence.[3]. Not only by the Greeks, Alexander was also despised by the Macedonians. Many Macedonians managed to form leagues with Greek city states to rebel against Alexander. Some noblemen in Macedonia even held protests against Alexander and promoted the other candidate Amyntas who was the son of Philip's brother to take the crown instead. Alexander could not lead an army where the men despised him. Meanwhile, things were no better outside of the kingdom as the Persians enacted currency diplomacy with the Greek city states and gave loads of money to these states to support their revolt against the Macedonians, affecting the Macedonian's interests greatly. Whether using military measures or propaganda, Alexander had to settle the turmoil. Indeed he at last did. But the city-states would feel forced under the Alexander's leadership and Alexander would not have liked to lead men who do not play by his rules. Alexander had to win respect and trust. He had to make the first move. Thus came the 300 suits of armor. Pieces of armor are what the winning side get as a result of victory. So the armor may act like trophies honored to the Greeks and as an invitation given to the them to ask them to remain a solid military foundation for Alexander. The pieces of armor would also have a deterrent effect, proving to the Greeks Alexander's strength and wit in fighting battles. But why did he dedicate the armor to the Athenians instead of other citystates?

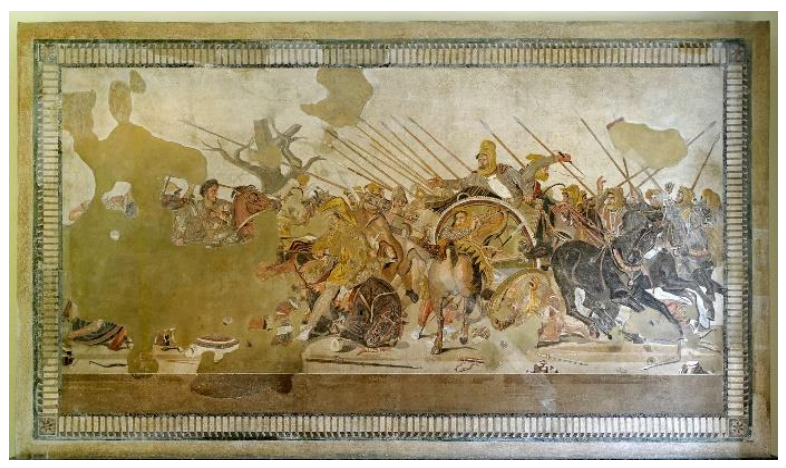

Figure 2 Alexander Mosaic from the House of the Faun, Pompeii

\section{SIGNIFICANCE OF THE DEDICATION}

\subsection{Implication of the Armor itself}

We know that Athens was named after the goddess Athena, who holds a high reputation in Greek religion. She was thought as the guard of Athens and the goddess of warfare. The Acropolis was the most prominent dedication to her. It witnessed the growth, wound, and revival of Athens in the ancient era. The Persians made their first invasion into Greece in the Battle of Marathon a century ago. Outnumbered, the Greek states still successfully exiled the Persians but the Acropolis was burned down. However, a statesman rebuilt it afterward. The Acropolis underwent another trauma in the Peloponnesian War by the Spartans but was still revered by the Greeks even after Philip II dominated Greece. The Acropolis also contains friezes that document significant myths and stories that took place in Greece. For example, the Temple of Athena Nike was exclusively built to mark the victory over the Persians. Part of the Parthenon's frieze was also devoted to a representation of the Battle of Marathon, where the Athenians turned the tide against the Persians[4]. This implies that the Acropolis was seen highly by the Greeks. It signifies the revival, wealth, and military strength of Greece. It also shows that the Athenians take warfare and their past with high regard. If Alexander sent the Acropolis the suits of armor, Athenians would treat them with caution as well. Also, the inscriptions were written in Greek. Thus this message was targeted at those literate Greeks, who could understand the hidden agenda of Alexander's inscription. Athens at that time was developing democracy and needed literate citizens to write down honors and laws to show to the public. Though not everyone could read the message, it was still an implication that the Athenians were very involved in political events and were concerned with the prospects of their state. In fact, Athens was such a strong city-state at that time that it had the highest civilization and was the birthplace of many notable statesmen, poets, and architects, signifying the 
Athenians' outstanding intelligence. Therefore, the Athenians would implement extra attention towards Alexander's message. It is important to point out that with the development of democracy and subjects such as philosophy, Athens turned out to be a very formidable state. After the Persians' first invasion in the 5th century B.C.E., Athens used its appeal and organized the Delian League to seek a stronger defense. Athens had the impact and charm on other states that Alexander sought. So if Alexander wanted to win the heart of the Greeks, he needed to win the heart of the Athenians.

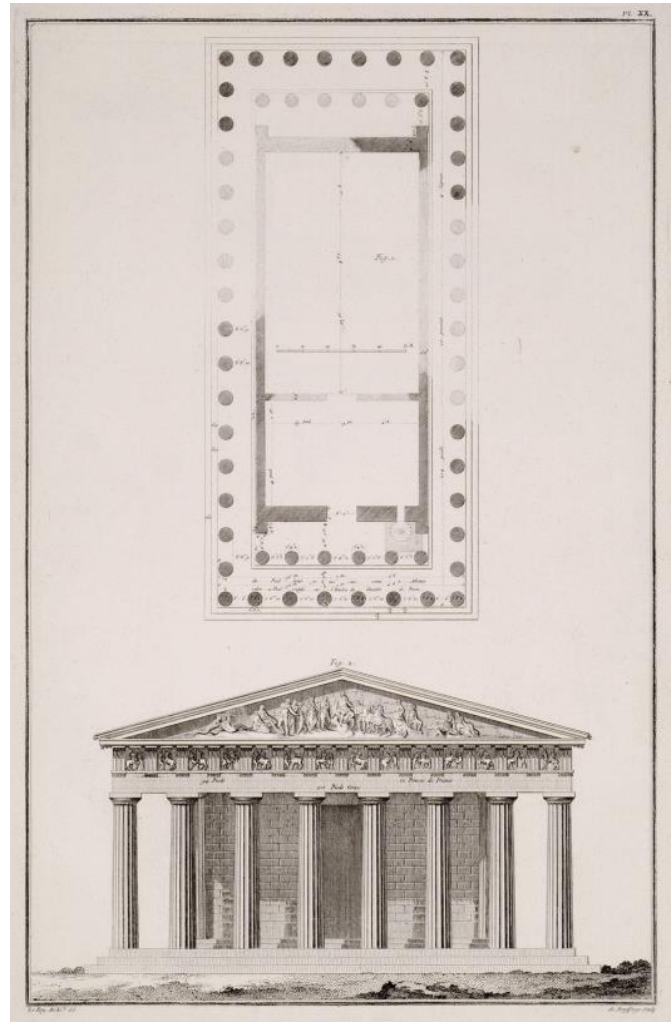

Figure 3 Plan of Parthenon, West side of the temple

\subsection{Implication of the inscription}

The first thing Alexander inscribed made clear of his identity. He explicitly refers to himself as the son of Philip. In ancient Greek, this was a tradition on how greeks introduce themselves - adding the name of their father. This tradition still exists in official Greek documents and influences other European cultures as well. For example, in Lord of the Rings, a film that emphasizes ancient culture and background, Aragorn introduces himself as "Aragorn, son of Arathorn". Thus, Alexander's introduction could be seen as a way of him adopting the Greek tradition, showing fondness for Greek culture, just like he did when he expressed his respect to the Greek Poet Pindar at Thebes[5]. Apart from following the Greek tradition, this introduction may also be seen as a deliberate act. It is worth mentioning that Alexander was more than the son of Philip. He grew up being constantly instilled with the fact that he was the descendant of Achilles, and shares blood with the gods. He was also the King of Macedon and the leader of the Corinth League. But why did he only mention the least noteworthy identity? What he says seems to show how he wanted the Greeks to see him. He was an honorable leader instead of a defiant monarch. These words of modesty would have a greater chance of forming a friendly and cooperative atmosphere in his army that would have longterm benefits in morale. Notably, as Philip was a prestigious leader himself, this claim could also be seen as a reemphasis towards Alexander's legitimacy in leadership, showing that leadership and wit were in his bones.

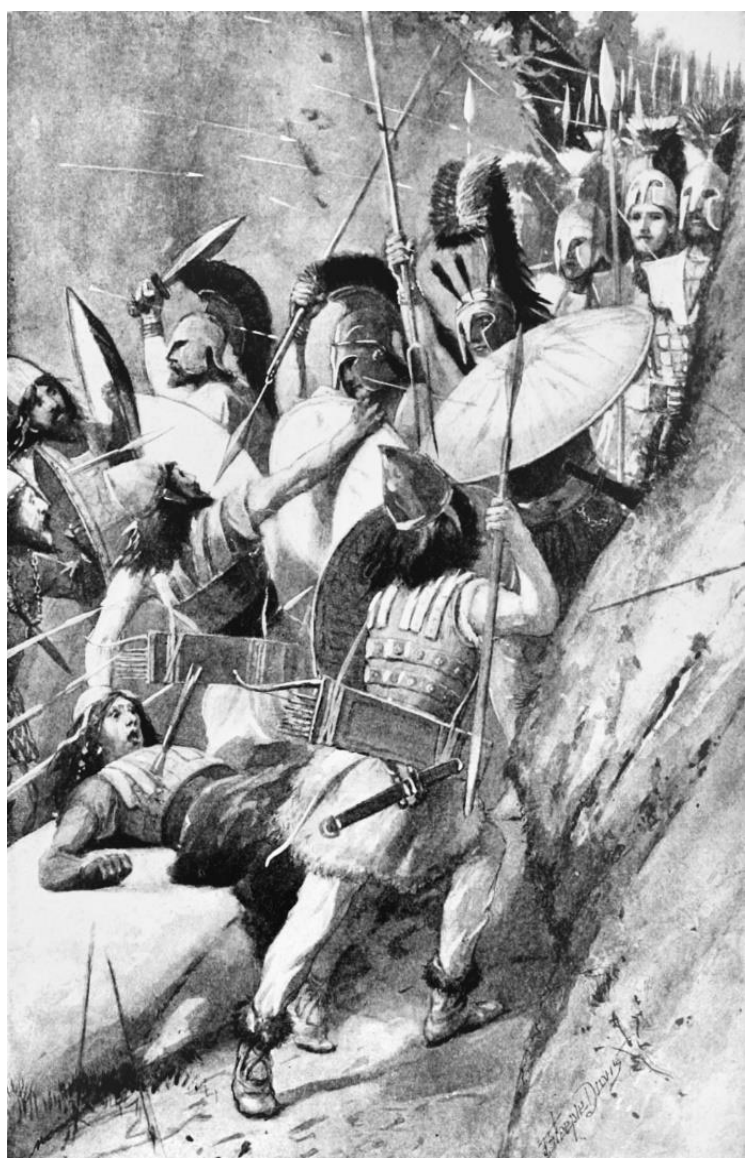

Figure 4 Battle of Thermopylae

Alexander also claimed that he was a descendant of the Greeks. He was probably trying to be one of the Greeks to earn trust. He was also crediting the Greeks to the success of the Battle of Granicus. In the meantime, he completely eliminated the Lacedaemonians from the picture. Lacedaemonians mainly refer to the Spartans. Sparta was widely known for its military competency and was the only city-state that refused to join the Corinth League. Alexander has full right to be furious about this act. Explicitly pointing out Sparta was not only a response to their refusal, but was also a hint for other Greek citystates on what would happen if they chose to turn Alexander down. This hint could also be seen as a threat to the members of the Corinth League, leaving them no 
space to quit. The grudge of the 21-year-old leader is shown, but his deterrence remains. Additionally, Sparta and Athenians have long been enemies. Their opposition to each other originated from the democratic reform of Cleisthenes and went into further opposition when Athens gained naval control over the Mediterranean sea. Alexander utilized the Athenians' hostility towards Sparta in order to gain solid support by mobilizing their emotions. Indeed, this was another way of Alexander showing the Greeks that "we are on the same team".

In the last part of the sentence, Alexander used the "foreigners inhabiting Asia". At that time, Persians dwelled in most parts of Asian Minor-from India to upstart cities of Greece and from the Red-Sea to Persian golf and also a small part of Egypt[6] - they were the dominators of the land. So this statement refers mostly to the Persians. The reason why he did not just inscribe "Persians" may be because his target was not merely Persia and he had wilder dreams of fully conquering all of Asia. Using the phrase "taken from" may also imply that taking the Persian Armor from one winning battle was only the first step of Alexander's ambition, he is now set off to take all Asian Minor territory. The wild vision of this 21-year-old his fully shown at this point. It makes clear to the Greeks that they must keep their guard up and prepare for further battles. Alexander was from now on unstoppable. And if we look at what happened before the Battle of Granicus, while Alexander and his army were marching forward in quest of the enemy, he told his soldiers not to ravage Asia, saying "they ought to spare their own property, and not destroy what they came to possess."[7] This just proves that Alexander had the idea of conquering Asia a long long time before. He was prepared. He had the ambition.

\subsection{Implication of the number three hundred}

One of the most intriguing parts of the inscription is the number of shields donated. As a thoughtful and wise man like Alexander himself, we infer that this number cannot be a random pick. This message may be traced back to the summer of 480 B.C.E. when the Persians were on their way to Attica but had to cross the land of Thermopylae that was controlled by the Greeks. A battle known as the Battle of Thermopylae emerged. It was in this Battle that Leonidas led 300 Spartans to fight. Of course, there were thousands of other Greek soldiers. But it was these Spartans that last stood against the Persian army and held the single-file pass at Anopaea to buy more time for other Greek soldiers to get away. Eventually, only one Sparta survived the battle, but their integrity and bravery remain an epic that would long be remembered[8]. This may be Alexander's way of complimenting the Athenians of their bravery in the Battle of Granicus and encouraging them to be brave in future battles. But it also shows that Alexander was still somehow respectable towards true warriors - the 300
Spartas, in spite of the "except the Lacedaemonians" mock on the inscription. This may be Alexander's way of showing his own integrity and objectivity towards Sparta, giving the Athenians hint into his character-he may be a boy, but he may also be a considerate leader with a broad heart - and that is why he should be trusted as a leader.

\section{CONCLUSION}

At least from what we know happened that later proved that the Athenians and other Greeks did get Alexander's message and assisted him in further conquests. In addition, he won the hearts of not only the Greeks but also the hearts of men he came across throughout his expedition. The 300 pieces of armor certainly do deserve credit. This episode in Alexander's conquest may not be as well-known as the battles, but it was indeed a great episode to learn about Alexander himself. For one thing, it earned Alexander the heart of the Greeks, underlining the Panhellenic nature of Alexander's conquest. For another, it reflects the character within Alexander, setting the tone for his remarkable expedition. He eventually made it all the way to India. Twelve years. Twenty-two thousand miles. His vision, his ambition and his leadership strategies would all be considered a cool part of his legacy. He stood there plain to all, but his almost legendary courage no less than his shining armor proclaimed him[9].

\section{REFERENCES}

[1]Arrian. The Anabasis of Alexander, Chapter XVI.Defeat of the Persians-Loss on Both Sides.

[2]T. Editors of Encyclopedia. (2018) "League of Corinth". https://www.britannica.com/topic/League-ofCorinth.

[3]Plutarch. Life on Alexander, 11.6

[4]T. Editors of Encyclopedia. (2018) "AcropolisAncient Greek District" https://www.britannica.com/technology/acropolisancient-Greek-district

[5]Thucydides, History of the Peloponnesian War, 1.98.2.

[6]Wikipedia. (2020) "List of Largest Empires". https://wiki2.org/en/List_of_largest_empires

[7]Justinus. Epitome of Pompeius Trogus' Philippic Histories, 11.6

[8]Kate Lohnes. (2017) "Battle of Thermopylae". https://www.britannica.com/event/Battle-ofThermopylae

[9]Arrian. The Anabasis of Alexander, Book 6. 